\title{
Quo Vadis Kebijakan Kawasan Agropolitan di Indonesia?
}

\author{
Sintaningrum ${ }^{1}$ \\ Tomi Setiawan ${ }^{2}$
}

\begin{abstract}
Abstrak
Agropolitan merupakan bentuk pembangunan yang memadukan pembangunan pertanian (sektor basis di perdesaan) dengan sektor industri yang selama ini secara terpusat dikembangkan di kota-kota tertentu saja. Secara luas pengembangan agropolitan berarti mengembangkan perdesaan dengan cara memperkenalkan fasilitas-fasilitas kota/modern yang disesuaikan dengan lingkungan perdesaan. Ini berarti tidak mendorong perpindahan penduduk desa ke kota, tetapi mendorong mereka untuk tinggal di tempat dan menanamkan modal di daerah perdesaan, karena kebutuhan-kebutuhan dasar (lapangan kerja, akses permodalan, pelayanan kesehatan, pelayanan pendidikan, dan kebutuhan sosial-ekonomi lainnya) telah dapat terpenuhi di desa. Hal ini dimungkinkan, karena desa telah diubah menjadi bentuk campuran yang dinamakan agropolis.
\end{abstract}

Kebijakan Agropolitan telah diimplementasikan di Indonesia sejak tahun 2002. Salah satunya berlokasi di Kab Cianjur. Meski sudah lama dan dianggap konsep yang tepat untuk mengembangkan agroindustri, Agropolitan di berbagai wilayah meredup kegiatannya. Dengan menggunakan pendekatan kualitatif, penelitian ini menggambarkan bagaimana implementasi kebijakan kawasan agropolitan, khususnya di Kabupaten Cianjur yang relatif lebih berkembang dibandingkan dengan kawasan agropolitan di wilayah lain di Indonesia.

Kata Kunci : tata kelola, sistem kelembagaan, kawasan agropolitan

\section{PENDAHULUAN}

Pembangunan kawasan agropolitan merupakan program nasional yang tidak hanya dilakukan di Cipanas Cianjur saja, namun juga dibangun di 8 kawasan agropolitan lain di seluruh Indonesia. Pembangunan kawasan agropolitan merupakan program yang bersifat lintas sektoral, yaitu melintasi sektor-sektor pertanian, perdagangan dan industri, dan pembangunan fisik sehingga pada permulaan pembangunannya paling tidak melibatkan 5 instansi pemerintah, yakni :

1. Pemerintah Pusat (Menkeu),

2. Depkimpraswil,

3. Pemerintah Daerah Kab. Cianjur,

4. Departemen Pertanian, dan

5. Deperindag.

Setiap institusi memiliki peran dan fungsinya masing-masing dalam membangun, mengembangkan, dan memelihara kawasan agropolitan agar sesuai dan mencapai tujuan

\footnotetext{
${ }^{1}$ Staf Pengajar pada Prodi Administrasi Publik, FISIP Universitas Padjadjaran. Email : sinta.ningrum@unpad.ac.id

${ }^{2}$ Staf Pengajar pada Prodi Administrasi Publik, FISIP Universitas Padjadjaran. Email :tomi_setiawan@yahoo.com
} 
pembangunannya. Sarana dan prasarana agropolitan menjadi tanggung jawab dan pendanaan Departemen Permukiman dan Prasarana Wilayah (Depkimpraswil) dengan nomenklatur Proyek Pengembangan Prsasarana dan Sarana Desa Agropolitan (P2SD-Agro) Direktorat Jendral Tata Perkotaan dan Tata Perdesaan Depkimpraswil. Departemen Pertanian bertanggungjawab dalam penataan dan pengembangan teknik pertanian. Sementara Pemda Cianjur bertanggung jawab dalam pengembangan dan pemeliharaan kawasan selanjutnya setelah diserahterimakan oleh pemerintah pusat. Deperindag berfungsi menjembatani pembeli dan memfasilitasi perdagangan hasil produksi pertanian.

Agropolitan adalah suatu konsep pembangunan berdasarkan aspirasi masyarakat bawah yang tujuannya tidak hanya meningkatkan pertumbuhan ekonomi, tapi juga mengembangkan segala aspek kehidupan sosial (pendidikan, kesehatan, seni-budaya, politik, pertahanan-keamanan, kehidupan beragama, kepemudaan, dan pemberdayaan pemuda dan kaum perempuan). Agropolitan merupakan bentuk pembangunan yang memadukan pembangunan pertanian (sektor basis di perdesaan) dengan sektor industri yang selama ini secara terpusat dikembangkan di kota-kota tertentu saja. Secara luas pengembangan agropolitan berarti mengembangkan perdesaan dengan cara memperkenalkan fasilitas-fasilitas kota/modern yang disesuaikan dengan lingkungan perdesaan. Ini berarti tidak mendorong perpindahan penduduk desa ke kota, tetapi mendorong mereka untuk tinggal di tempat dan menanamkan modal di daerah perdesaan, karena kebutuhan-kebutuhan dasar (lapangan kerja, akses permodalan, pelayanan kesehatan, pelayanan pendidikan, dan kebutuhan sosial-ekonomi lainnya) telah dapat terpenuhi di desa. Hal ini dimungkinkan, karena desa telah diubah menjadi bentuk campuran yang dinamakan agropolis atau kota di ladang.

Dalam konteks spasial, proses pembangunan yang telah dilaksanakan selama ini telah menimbulkan berbagai permasalahan yang berkaitan dengan tingkat kesejahteraan antar wilayah yang tidak berimbang. Hal ini terutama bisa dilihat dari interaksi antara desa-kota yang secara empiris seringkali menunjukkan suatu hubungan yang saling memperlemah. Berkembangnya kota sebagai pusat-pusat pertumbuhan ternyata tidak memberikan efek penetesan ke bawah (trickle down effect), tetapi justru menimbulkan efek pengurasan sumberdaya dari wilayah di sekitarnya (backwash effect).

Pengembangan agropolitan adalah pengembangan berbagai hal yang dapat memperkuat fungsi atau peran agropolis sebagai lokasi pusat pelayanan sistem kawasan sentrasentra aktivitas ekonomi berbasis pertanian. Tipologi pengembangan disesuaikan dengan karakteristik tipologi kawasan yang dilayaninya (Saefulhakim 2004). Agropolitan adalah suatu wilayah hamparan agro (pertanian) yang memiliki distrik (kawasan) agropolitan dan pusat-pusat agropolisnya (kota-kota pertanian) (Harun 2004).

Tingkat kemajuan atau perkembangan kawasan agropolitan ditunjukkan dengan indikator komponen berikut :

1. Infrastruktur

Infrastruktur di kawasan agropolitan terdiri atas infrastruktur di desa-desa pusat pertumbuhan atau sentra produksi yang menunjang pada peningkatan produktivitas; infrastruktur di pusat kawasan yang menujang pengolahan dan pemasaran hasil produksi komoditas; serta Infrastruktur pendukung keterkaitan desa-kota untuk pemasaran keluar dalam lingkup pengembangan wilayah.

2. Sumber daya alam (antara lain, komoditas berdasarkan unggulan /keunikan)

Komoditas unggulan dikawasan agropolitan sebagai ujung tombak peningkatan ekonomi, ditetapkan yang mempunyai daya saing komparatif dan kompetitif, harga jual yang relatif stabil, selain itu komoditas dapat diolah dalam berbagai produk sehingga mempunyai nilai tambah harga jual dan dapat menyerap tenaga kerja yang besar.

3. Sumber daya manusia

Sumberdaya manusia di kawasan agropolitan sebagian besar bekerja di sektor komoditas 
unggulan. Sumber daya manusia yang ada didorong semakin kreatif dan inovatif terhadap penerapan teknologi peningkatan produktivitas dan pemasaran produksi. Sumberdaya manusia semakin produktif apabila mempunyai tempat tinggal dalam lingkungan permukiman yang relatif lebih baik (Dardak 2004).

Kawasan agropolitan yang saat ini dikembangkan di wilayah Cianjur sudah ditetapkan melalui : Surat Menteri Pertanian No. 144/OT.210-A/V-2002 Tentang Penunjukan salah satu Kabupaten Wilayah pengembangan Agropolitan, dan Penetapan Master Plan Keputusan Bupati No. 521.3/Kep.140-Pe 202 Tanggal 2 Mei 2002. Dalam konteks tata keloa kawasan agropolitan Cipanas Cianjur, banyak kalangan yang menilai pemerintah Kabupaten Cianjur kurang serius menangani kawasan Agropolitan yang terletak di Desa Sindangjaya dan Desa Sukatani Kecamatan Cipanas yang diresmikan pada tahun 2002 lalu. Pasalnya, kawasan agropolitan yang dibangun dengan menghabiskan biaya sekitar $\mathrm{Rp}$ 3,2 milyar bersumber dari dari pemerintah pusat melalui Departemen Permukiman dan Prasarana Wilayah (Kimpraswil), kini kondisinya seakan kurang terurus dan berkembang. Padahal dari segi potensi alam kawasan tersebut sangat berpotensi untuk dikembangkan hingga menjadi salah satu sektor pendapatan. apabila dijadikan pusat sayurmayur atau kawasan wisata. Sejatinya kawasan agropolitan seharusnya bisa dikembangkan lantas dijadikan pusat hasil pertanian. Bahkan, selebihnya bisa dijadikan tempat wisata atau penelitian mengenai sayur-mayur. Ini artinya, konsep agropolitan tidak tuntas dan tidak memberdayakan petani lokal.

Berdasarkan latar belakang di atas, permasalahan penelitian dirumuskan sebagai berikut : Bagaimanakah efektivitas kebijakan kawasan agropolitan di Indonesia, khususnya di Kawasan Agropolitan Cianjur? Adapun tujuan penelitian adalah menggambarkan efektivitas kebijakan kawasan agropolitan di Indonesia, dengan mengambil kasus di Kawasan Agropolitan Cianjur.

\section{KAJIAN PUSTAKA}

\subsection{Konsep Agropolitan}

Perkembangan dan sejarah konsep pembangunan wilayah mengalami perubahan yang dinamis. Pertama, dimulai dengan konsep teori central place dari Christaller pada tahun 1933. Konsep ini bertujuan ingin menjelaskan pilihan-pilihan lokasi untuk sektor-sektor publik dan pribadi, serta dimana posisi pemerintah mengambil keputusan sehingga menghasilkan alokasi yang optimal bagi berbagai fungsi layanan ekonomi. Kedua, konsep neoklasik. Konsep ini menyatakan bahwa penggunaan sumber daya dapat menjadi optimum dan distribusi pendapatan dan pertumbuhan antar wilayah akan merata apabila mekanisme pasar berfungsi sebagaimana mestinya. Ketiga, teori growth pole, konsep ini berkembang di Perancis pada tahun 1950 dimana suatu industri tertentu perlu dikembangkan dengan berbagai fasilitas pendukungnya sehingga menstimulasi berbagai aktifitas ekonomi di wilayah sekitarnya. Keempat, teori export base, teori berkembang di Amerika Serikat pada awal dekade lima puluhan, dimana pertumbuhan wilayah dipicu oleh permintaan eksternal. Selanjutnya pendapatan yang diterima dari ekspor digunakan untuk menstimulasi permintaan internal dan pertumbuhan wilayah. Kelima, centre-peripherymodels, model dicetuskan oleh Gunard Myrdal pada tahun 1957 sebagai pertanyaan terhadap penerapan model neoklasik di negara berkembang. Myrdal mengatakan bahwa negara berkembang tidak mungkin berdampingan dengan negara maju dalam kerangka mekanisme pasar, karena akan menghasilkan kesenjangan yang makin parah. Model Myrdal baru diakui pada awal tujuh puluhan sebagai paradigma baru pembangunan. Myrdal menginginkan feri-feri harus memperoleh perhatian yang proporsional agar kesenjangan dapat dihentikan. Konsep pembangunan agropolitan diangkat dari pemikiran Myrdal dalam konteks yang lebih spesifik, yakni keadaan negara-negara Asia yang umumnya berpenduduk padat, serta sistem pertaniannya labor intensive dalam skala usaha 
kecil.

Friedmann and Douglas (1978) dalam Mercado (2002) mengimplementasikan gagasan Myrdal kedalam konsep pembangunan agropolitan. Agropolitan merupakan pendekatan perencanaan pembangunan tipe bottom-up yang berkeinginan mencapai kesejahteraan dan pemerataan pendapatan lebih cepat dibanding strategi growth pole. Karakteristik agropolitan meliputi (i) skala geografi relatif kecil, (ii) proses perencanaan dan pengambilan keputusan yang bersifat otonom dan mandiri berdasarkan partisipasi masyarakat lokal, (iii) diversifikasi tenaga kerja pedesaan pada sektor pertanian dan non pertanian, menekankan kepada pertumbuhan industri kecil (iv) adanya hubungan fungsional industri pedesaan - perkotaan dan linkages dengan sumberdaya ekonomi lokal, dan (v) pemanfaatan dan peningkatan kemampuan sumberdaya dan teknologi lokal. Selanjutnya Friedmann and Weaver (1979) menyempurnakannya sebagai strategi pembangunan wilayah (pedesaan maupun perkotaan) yang bertumpu pada sumberdaya lokal dengan dukungan implementasi dalam aspek politik, ekonomi dan sosial, untuk mencapai sasaran (i) diversifikasi aktifitas ekonomi, (ii) mendorong ekspansi pasar regional (bahkan dengan substitusi impor), (iii) mendorong perputaran modal (recirculation) di dalam masyarakat, dan (iv) mendorong proses pembelajaran. Friedmann dalam Syahrani (2001), menyatakan bahwa di dalam wilayah agropolitan disediakan berbagai fungsi layanan untuk mendukung berlangsungnya kegiatan agribisnis. Fasilitas pelayanan meliputi sarana produksi (pupuk, bibit, obatobatan, peralatan), sarana penunjang produksi (lembaga perbankan, koperasi, listrik), serta sarana pemasaran (pasar, terminal angkutan, sarana transportasi).

Dalam konsep agropolitan juga diperkenalkan adanya agropolitan distrik, yakni suatu daerah perdesaan dengan radius pelayanan 5 hingga $10 \mathrm{~km}$ dan dengan jumlah penduduk 50 hingga 150 ribu jiwa serta kepadatan minimal 200 jiwa per $\mathrm{km}^{2}$. Jasa-jasa dan pelayanan yang disediakan disesuaikan dengan tingkat perkembangan ekonomi dan sosial budaya setempat. Sekalipun konsep Friedmann dan kawan-kawan dapat dianggap sebagai definisi baku, namun muncul pula tafsiran, varian atau yang berdekatan dengan definisi agropolitan. Misalnya, model selective spatial closure. Model ini menjelaskan bahwa pembangunan dapat dilakukan secara selektif terhadap wilayahwilayah tertentu dan dengan alasan tertentu pula. Misalnya industri pada wilayah feri-feri dapat diberi perhatian, atau harus dilindungi dari kompetisi dengan industri yang sama di wilayah center. Oleh sebab itu infrastruktur lokal harus diperkuat sebagai antisipasi dari dampak ekonomi yang lebih global. Kebijakan diarahkan secara spesifik kepada pemenuhan kebutuhan dasar dari masyarakat lokal dalam berproduksi (basic need and target group -oriented) bukan dengan pendekatan teknis untuk masyarakat secara umum. Model lain sebagai bagian dari agropolitan adalah yang disebut dengan locally integrated economic circuit atau (LIEC), yakni sistem ekonomi wilayah lokal yang terdiversifikasi dan terintegrasi, mandiri, dinamis, didominasi aktifitas ekonomi skala usaha kecil, yang menjalankan proses alokasi sumberdaya secara harmonis dan berkesinambungan. Model LIEC menuntut pendefinisian batasan wilayah yang relevan, potensi sumber daya wilayah, kapasitas industri, teknologi lokal tepat guna, dan dukungan kelembagaan.

Konsep lainnya adalah apa yang disebut dengan Sustainable Integrated Planning (SIP). Pembangunan agropolitan menurut model SIP menjelaskan sisi-sisi praktis dari implementasi pembangunan berkelanjutan. Dalam pandangan SIP, pembangunan dapat dilaksanakan jika landasan perencanaan dicukupi. Perencanaan menjadi panduan pelaksanaan pembangunan pada semua level, nasional, provinsi dan wilayah. Menurut Scrimgeour, Chen and Hughes (2002), pembangunan agropolitan yang disebutnya sebagai "self-centred development" memerlukan intervensi pemerintah dalam bentuk regulasi untuk memotong hambatan-hambatan struktural. Upaya tersebut bertujuan agar terjadi integrasi sosial ekonomi di dalam wilayah dengan budaya, sumberdaya, lansekap dan iklim tertentu. Lebih 
jauh, kebutuhan investasinya dapat didatangkan dari luar wilayah jika kemampuan lokal relatif rendah. Dengan kata lain, alokasi sumber daya wilayah merupakan komponen penting pembangunan agropolitan bersama-sama dengan aspek ekologi dan sosial. Secara umum pendekatan dari pembangunan agropolitan telah dapat diterima. Berbagai negara sudah menerapkan sekalipun dengan istilah yang beragam. Pemerintah Cina menerapkannya dalam istilah walking on the legs. Satu kaki berpijak kepada kebijakan untuk mendorong pertumbuhan dengan mengandalkan industri skala besar, sementara kaki lainnya menerapkan konsep agropolitan untuk mengembangkan aktifitas ekonomi wilayah lokal. Sementara Afrika Selatan menerapkan kebijakan Growth with Equity and Redistribution (GEAR) pada tahun 1996 (Simon, 2000). Demikian pula, pendekatan ini juga telah menjadi program baku Bank Dunia di dalam kerangka community base development untuk pengentasan kemiskinan, pemberdayaan ekonomi masyarakat pedesaan (usaha kecil), atau pengembangan kredit mikro. Definisi baku mengenai pembangunan agropolitan di Indonesia belum jelas dinyatakan.

Menurut Depkimpraswil, program agropolitan mengandung pengertian pengebangan suatu wilayah tertentu yang berbasis pada pertanian. Depkimpraswil memiliki kepentingan dalam penyediaan sarana dan prasarana wilayah sementara Deptan bertanggung jawab terhadap aspek produksi pertanian. Sementara itu pemerintah kabupaten Kutai Timur mendefinisikan Agropolitan sebagai sistem manajemen dan tatanan terhadap suatu wilayah yang menjadi pusat pertumbuhan bagi kegiatan ekonomi berbasis pertanian (agribisnis/agroindustri). Wilayah agropolitan diharapkan akan menarik pengembangan ekonomi berbasis agri di wilayah hinterland, dan oleh karenanya perlu diciptakan suatu Linkage dan keterpaduan antara kawasan Agropolitan dengan kawasan hinterland.

Agropolitan merupakan kota pertanian yang tumbuh dan berkembang karena berjalannya sistem dan usaha agribisnis serta mampu melayani, mendorong dan menarik kegiatan pembangunan pertanian di wilayah sekitarnya (Rivai, 2003). Kota pertanian (agropolitan) berada dalam kawasan sentra produksi pertanian yang memberikan kontribusi besar terhadap mata pencaharian dan kesejahteraan masyarakatnya.

Menurut Nasoetion (1999) dalam Hastuti (2001), paradigma konsep agropolitan adalah (1) hubungan perdesaan dengan kota-kota dapat mencapai suatu tingkat sinergisme sepanjang hubungan fungsional dari sub-wilayah tersebut menghasilkan nilai tambah yang dapat diredistribusikan melalui pengembangan suatu tatanan institusional yang secara benar menggambarkan status kelangkaan suatu sumberdaya atau komoditas, (2) apabila terjadi akumulasi modal, terdapat mekanisme pasar yang dapat mengalirkan modal kepada penggunaan yang dapat memberikan manfaat sosial terbesar, dan (3) perkembangan pusat pertumbuhan (kota) pada suatu tingkat akan mengalami deminishing return sehingga harus dibatasi melalui mekanisme pasar.

Rivai (2003) menyatakan bahwa pengembangan kawasan agropolitan merupakan alternatif solusi untuk pengembangan wilayah perdesaan. Konsep pengembangan agropolitan tidak semata-mata ditujukan kepada pembangunan fisik material, tetapi juga sekaligus harus dikaitkan dengan pembangunan masyarakat (sumberdaya manusia) secara langsung. Titik berat pembangunan masyarakat, khususnya masyarakat setempat memerlukan pendekatan yang bersifat integral dan terpadu, artinya pembangunan yang akan dilaksanakan tidak hanya menyangkut pembangunan struktur fisik, tetapi sekaligus pembangunan manusia dengan pendekatan yang berimbang. Tata kelola kawasan agropolitan harus mempunyai keterkaitan yang harmonis dengan kombinasi antara pendekatan yang top down dengan pendekatan bottom up yang bertujuan untuk mencapai efek ganda (multiplier effect). Prakarsa-prakarsa dari bawah tidak dapat diabaikan, karena merupakan invisible hand dalam menggerakkan sumberdaya-sumberdaya yang ada sebagai kekuatan utama untuk mewujudkan pengembangan kawasan agropolitan yang berkelanjutan dan berwawasan lingkungan. 
Tata kelola kawasan agropolitan merupakan upaya untuk menumbuhkan kegiatan ekonomi berbasis pertanian dengan memperkuat keterkaitan sektoral antara pertanian, non pertanian dan jasa penunjangnya serta keterkaitan spasial antara wilayah perdesaan dan perkotaan.

Di sisi lain, suatu sistem kelembagaan terkait dengan proses dimana anggota-anggota masyarakat meningkatkan kapasitas kelembagaannya untuk memobilisasi dan mengelola sumberdaya untuk menghasilkan perbaikanperbaikan yang berkelanjutan dan merata dalam kualitas hidup sesuai dengan aspirasi mereka. Oleh karena itu, dalam perkembangannya, kelembagaan dan kelembagaan lokal di kasawan agropolitan Pacet Kabupaten Cianjur dapat dilacak dari aspek historis atau riwayat (proses atau dinamikanya) dan keberlanjutan kelembagaan tersebut (institutional sustainability). Secara konseptual, sejarah atau riwayat perkembangan kelembagaan tersebut erat kaitannya dengan keberlanjutan kelembagaan tersebut.

Dengan berlandaskan kepada pendekatan tersebut, dalam perumusan bentuk kelembagaan dan kelembagaan lokal di kasawan agropolitan Pacet Kabupaten Cianjur, maka harus diidentifikasi beberapa prinsip yang sangat penting untuk dipertimbangkan. Pertama, kelembagaan tersebut merupakan manifestasi dari "sharing" seluruh stakeholder, dimana peranan dari masing-masing stakeholder dalam kelembagaan tersebut (pola hubungan) dapat ditelaah secara kritis dari analisis pihak-pihak terkait. Telaah ini penting terutama untuk menetapkan dimana kedudukan organisasi atau badan yang melaksanakan fungsi hubungan kelembagaan tersebut. Kedua, fokus "pekerjaan" kelembagaan tersebut adalah kepada aktivitas yang partisipatif dan diperkirakan secara operasional dapat didukung dan difasiliatsi oleh beragam kebijakan local government. Oleh karena itu, untuk memperkirakan hal tersebut perlu dirumuskan suatu matriks antara "programprogram partisipatif" dengan "persyaratan kebijakan makro dan regional" yang dapat mengidentifikasi "beragam kebijakan apa saja yang perlu dirumuskan oleh local government."
Ketiga, kelembagaan tersebut baik secara konseptual maupun operasional mampu mengimplementasikan kaidah-kaidah desentralisasi dan otonomi daerah. Prinsip ini penting, terutama untuk mendukung aksi-aksi kolektif partisipatif dan sampai sejauh mana local government mampu membiayai beragam implementasi dari aktivitas partisipatif tersebut. Konsep tersebut tergambar pada gambar berikut ini.

\section{Gambar 2.1}

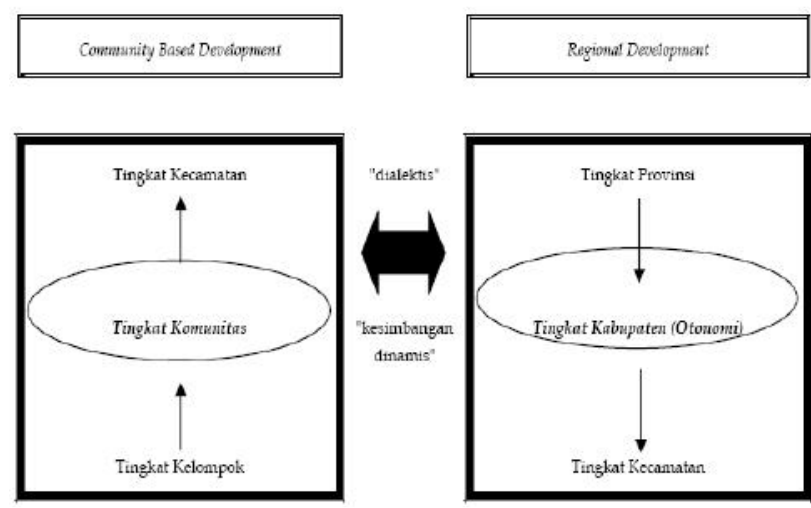

Keseimbangan Dinamis dan Hubungan Dialektis antara Community Based Development dan Regional Development

Oleh karena itu, aksi-aksi tersebut perlu berlandaskan pada "pemetaan sosial" yang dibangun dan dirumuskan bersama antar Participatory Sektor, Public Sektor, dan Private Sektor dalam suatu Kajian Bersama (Cooperative Inquiry) dengan model seperti pada gambar berikut ini.

Gambar. 2.2

Ruang-ruang kekuasaan pembentuk Sistem Tata kelola dan kelembagaan Kawasan

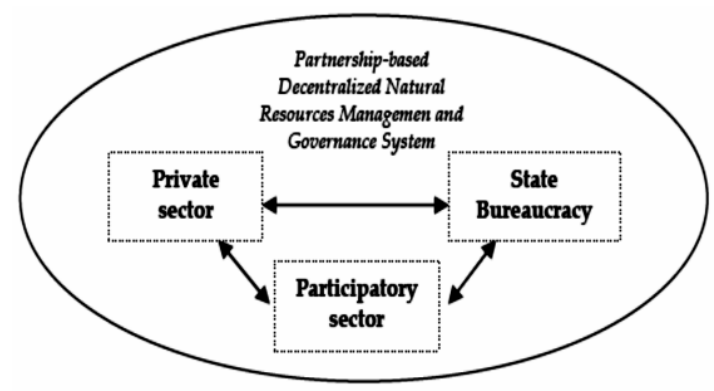


Penerapan pemberdayaan dalam pengelolaan kawasan agropolitan diharapkan memberikan beberapa dampak positif, yaitu: pertama, Menciptakan rasa memiliki dan tanggung jawab diantara semua pihak terkait dalam kawasan agropolitan, sehingga penge-lolaan kawasan agropolitan bisa berjalan efektif dan berkesinambungan. Kedua, adanya peran bagi semua stakeholders untuk terlibat dalam pembangunan dan pemeliharaan kawasan agropolitan, khususnya dalam hal pengambilan dan pertanggungan jawab keputusan sehingga semua stakeholders terberdayakan.

\section{Metode Penelitian}

Pendekatan yang digunakan dalam penelitian ini adalah pendekatan kualitatif dengan tipe deskriptif, yang dimaksud dengan pendekatan kualitatif adalah " pendekatan yang temuan-temuannya tidak diperoleh melalui prosedur stastistik atau bentuk hitungan lainnya" (Rahman \& Muh. Azis, 2006:10), tetapi mendeskripsikan data berdasarkan hasil pengamatan, tanpa dimanipulasi oleh peneliti.

Data yang dibutuhkan dalam penelitian ini dibagi menjadi 2 (dua) jenis data, yaitu data sekunder dan data primer. Data sekunder diperoleh dari beberapa literatur penting, seperti statistik, laporan hasil penelitian, hasil kajian, jurnal, surat khabar, majalah, buletin, dan sebagainya yang menunjang kelengkapan data penelitian ini. Jenis data lainnya adalah data primer. Data primer diperoleh dari berbagai fenomena yang terjadi di lapangan, baik yang dikumpulkan dari hasil wawancara berdasarkan panduan wawancara yang tersedia, maupun dari hasil pengamatan langsung yang kesemuanya mencerminkan keadaan/kondisi tempat penelitian. Wawancara dilakukan secara terbuka dengan indepth interview kepada informan kunci (key informan) yang mengetahui dan terlibat langsung dalam pembangunan dan pemeliharaan kawasan agropolitan Cipanas Cianjur. Pemilihan key informan dilakukan secara snowball. Wawancara dilakukan dengan ketua P4S, pengurus agropolitan, dan petani anggota kelompok tani. Data hasil wawancara selanjutnya dianalisis secara kualitatif.
Teknik analisis data selama di lapangan yang digunakan penulis sesuai dengan kebutuhan adalah menurut model Miles dan Huberman sebagaimana dikutip oleh Sugiyono. Aktivitas yang dilakukan dalam model ini adalah sebagai berikut:

a) Data Reduction (Reduksi Data)

Mereduksi data berarti merangkum, memilih hal-hal yang pokok, memfokuskan pada halhal yang dianggap penting, di ari tema dan polanya. Hal yang dipandang asing ketika mereduksi data harus disajikan fokus pengamatan untuk selanjutnya.

\section{b) Data Display (Penyajian Data)}

Display data dilakukan dengan teks yang naratif yang bersifat naratif, uraian singkat, bagan, dan hubungan antar kategori. Melalui penyajian data tersebut,maka data terorganisasikan, tersusun dalam pola hubungan, sehingga akan semakin mudah dipahami.

\section{c) Conclution Drawing/Verification}

Langkah ke tiga dalam analisis data kualitatif adalah penarikan kesimpulan atau verifikasi. Kesimpulan awal yang dikemukakan masih bersifat sementara, dan akan berubah bila tidak ditemukan bukti-bukti yang kuat yang mendukung pada tahap pengumpulan data berikutnya. Tetapi apabila kesimpulan yang dikemukakan pada tahap awal, didukung oleh bukti-bukti yang valid dan konsisten saat peneliti kembali ke lapangan mengumpulkan data, maka kesimpulan yang dikemukakan merupakan kesimpulan yang kredibel. (Sugiyono,2007:91-99)

Analisa data dilakukan untuk menyederhanakan data ke dalam bentuk yang lebih sederhana sehingga mudah dibaca dan dipahami, serta dapat mengambil kesimpulan secara tepat dan sistematis.

\section{Pembahasan}

Agropolitan diartikan sebagai upaya pengembangan kawasan pertanian yang tumbuh dan berkembang karena berjalannya sistem dan 
usaha agribisnis, yang diharapkan dapat melayani dan mendorong kegiatankegiatan pembangunan pertanian (agribisnis) di wilayah sekitarnya (Affendi Anwar,1999). Menurut Menkimpraswil, Kawasan agropolitan merupakan sistem fungsional desadesa dengan hirarki keruangan desa, yakni adanya pusat agropolitan dan desa-desa di sekitarnya. Sedangkan pusat agropolitan terkait dengan sistem pusat nasional, propinsi, dan kabupaten, dengan ciri berjalannya sistem dan usaha agribisnis di pusat agropolitan yang melayani dan mendorong kegiatan pembangunan pertanian (agribisnis) di wilayah sekitarnya. (Menkimpraswil, 2006)

Menurut Syahrani (2001), konsep agropolitan distrik dari Friedmann telah terbentuk sebagai pusat-pusat pelayanan di wilayah perdesaan. Hal tersebut dicirikan dengan adanya pasar-pasar untuk pelayanan masyarakat perdesaan. Mengingat volume permintaan dan penawaran yang masih terbatas dan jenisnya berbeda, maka telah tumbuh pasar mingguan untuk jenis komoditi yang berbeda. Di Jawa, pusat-pusat pelayanan tersebut dikenal dengan nama pasar Pahing, Pon, Wage atau Kliwon, sedangkan di Jakarta dikenal dengan nama pasar
Tabel 1 Wilayah Agropolitan di Indonesia

\begin{tabular}{|c|c|c|c|}
\hline NO & PROPINSI & $\begin{array}{c}\text { KOTA/KABUPATEN } \\
\text { AGROPOLITAN }\end{array}$ & $\begin{array}{c}\text { KOMODITI/BASIS } \\
\text { AGRIBISNIS }\end{array}$ \\
\hline 1 & $\begin{array}{l}\text { Sumatera } \\
\text { Barat }\end{array}$ & Agam & Sapi \\
\hline 2 & Bengkulu & Rejang Lebong & Jagung, Sayuran \\
\hline 3 & Jawa Barat & Cianjur & $\begin{array}{l}\text { Sayuran, } \\
\text { bungaan }\end{array}$ \\
\hline 4 & $\begin{array}{l}\text { DI } \\
\text { Yogyakarta }\end{array}$ & Kulon Progo & Biofarmaka \\
\hline 5 & Bali & Bangli & Kopi, Jeruk \\
\hline 6 & $\begin{array}{l}\text { Sulawesi } \\
\text { Selatan }\end{array}$ & Barru & Sapi \\
\hline 7 & Gorontalo & Boalermo & Jagung \\
\hline 8 & $\begin{array}{l}\text { Kalimantan } \\
\text { Timur }\end{array}$ & Kutai Timur & Coklat, Jagung \\
\hline 9 & NAD Aceh & Aceh Besar & Sapi \\
\hline 10 & $\begin{array}{l}\text { Sumatera } \\
\text { Utara }\end{array}$ & $\begin{array}{lr}\text { Tapanuli } & \text { Utara, } \\
\text { Simalungun, } & \text { Toba } \\
\text { Samosir, Dairi dan Karo }\end{array}$ & Sayuran \\
\hline 11 & Lampung & Lampung Tengah & Padi, Jagung, Kedele \\
\hline 12 & Babel & Belitung & Manggis, Lada \\
\hline 13 & Riau & Indragiri Hilir & Kelapa, Padi \\
\hline 14 & Jambi & Tanjung Jabung Timur & Kedele, Sapi Potong \\
\hline 15 & $\begin{array}{l}\text { Sumatera } \\
\text { Selatan }\end{array}$ & $\begin{array}{lcc}\text { Ogan Komering } & \text { Ilir } \\
(\mathrm{OKI}), \mathrm{Ulu}(\mathrm{OKU}) & \\
\end{array}$ & Padi, Hortikultura \\
\hline 16 & Banten & Pandeglang & Palawija, Durian \\
\hline 17 & Jawa Barat & Kuningan & Sapi \\
\hline 18 & Jawa Tengah & Semarang, Pemalang & $\begin{array}{l}\text { Tanaman } \text { Hias, } \\
\text { Farmaka, Sapi }\end{array}$ \\
\hline 19 & Jawa Timur & Mojokerto, Banyuwangi & Palawija \\
\hline 20 & Bali & Tabanan & Peternakan \\
\hline 21 & $\begin{array}{l}\text { Nusa } \\
\text { Tenggara } \\
\text { Barat } \\
\end{array}$ & Dompu & Sapi \\
\hline 22 & $\begin{array}{l}\text { Nusa } \\
\text { Tenggara } \\
\text { Timur }\end{array}$ & Kupang & Sapi \\
\hline 23 & $\begin{array}{l}\text { Sulawesi } \\
\text { Utara }\end{array}$ & Minahasa & $\begin{array}{ll}\begin{array}{l}\text { Kentang, } \\
\text { Sayuran }\end{array} & \text { Wortel, } \\
\end{array}$ \\
\hline 24 & $\begin{array}{l}\text { Sulawesi } \\
\text { Tengah }\end{array}$ & Donggala & Kakao, Sapi, Ikan \\
\hline 25 & $\begin{array}{l}\text { Sulawesi } \\
\text { Tenggara }\end{array}$ & Kendari & Sapi \\
\hline 26 & $\begin{array}{l}\text { Kalimantan } \\
\text { Selatan }\end{array}$ & Hulu Sungai Tengah & Jeruk, Sayuran \\
\hline 27 & $\begin{array}{l}\text { Kalimantan } \\
\text { Tengah }\end{array}$ & Kapuas & Sapi \\
\hline 28 & $\begin{array}{l}\text { Kalimantan } \\
\text { Barat }\end{array}$ & Pontianak & $\begin{array}{l}\text { Lidah Buaya, Pepaya, } \\
\text { Sayuran }\end{array}$ \\
\hline 29 & Papua & Jayapura & Kakao \\
\hline
\end{tabular}

Nomor 1 hingga 8 ditetapkan tahun 2002, Nomor 9 hingga 29 ditetapkan tahun 2003. (Sumber: www.deptan.go.id) 
Pentingnya keterpaduan semakin memperluas cakupan wilayah agropolitan. Propinsi Sumatera Utara mengembangkan Kawasan Agropolitan Dataran Tinggi Bukit Barisan (KADTBB) yang terdiri lima Kabupaten. Keterkaitannya yang sangat erat dengan daerah dataran medium dan rendah dalam sistem agribisnis, sehingga menghasilkan hubungan antar wilayah tidak dapat dipisahkan sama sekali. Total luas KADTBB mencapai 19.162,25 km² yang terdiri dari 79 kecamatan, mencakup kabupaten-kabupaten Tapanuli Utara (6.062 $\mathrm{km}^{2}$ ), Simalungun (4387 $\left.\mathrm{km}^{2}\right)$, TobaSamosir $\left(3441 \mathrm{~km}^{2}\right)$, Dairi $\left(3146 \mathrm{~km}^{2}\right)$, dan Karo $(2127$ $\mathrm{km}^{2}$ ). Wilayah agropolitan propinsi Sumatera Selatan juga melibatkan dua kabupaten, yakni Ogan Komering Ilir (OKI) dan Ogan Komering Ulu (OKU). Wilayah agropolitan Kabupaten Kutai Timur, propinsi Kalimantan Timur telah memiliki konsep pembangunan agropolitan yang cukup baik, yang diberi nama Agropolitan Sangsaka (singkatan dari Sangkulirang, Sangata dan Kaliurang, nama wilayah di kabupaten tersebut). Langkah-langkah yang telah dilakukan meliputi :

a. Menetapkan batasan wilayah Agropolitan Sangsaka, dimana Maloy sebagai pusat Agroindustri dan pusat pertumbuhan.

b. Melakukan zonasi komoditas di kabupaten Kutai Timur dan menetapkan wilayahpengembangan lain yang berfungsi sebagai satelit pertumbuhan dari Agropolitan Sangsaka atau pusat pertumbuhan Agribisnis orde kedua.

c. Mengembangkan infrastruktur pendukung, seperti transportasi, komunikasi, air bersih dan energi bagi wilayah agropolitan maupun pengembangan agribisnis diwilayah pendukungnya Faktor-faktor pendukung pembangunan Agropolitan Sangsaka, meliputi :

(1) Luas wilayah Sangsaka mencukupi sebagai pengembangan agropolitan, yaknisedikitnya 25 ribu hektar.

(2) Pelabuhan samudra dengan kapasitas bongkar muat 7000 ton, dan dapat menjadipelabuhan transit ke Indonesia Timur.
(3) Jalan Arteri (trans Kalimantan) Sangatta-Samarinda-Balikpapan

(4) Jumlah populasi penduduk SangSaKa sekitar 300.000 jiwa

(5) Kondisi agroklimat sangat sesuai untuk pengembangan komoditas agribisnis

\section{Sistem Tata Kelola Kawasan Agropolitan di Kabupaten Cianjur}

Agropolitan adalah proyek percontohan yang tengah dikembangkan Departemen Pertanian dengan tujuan untuk mewujudkan suatu kota yang bernuansa pedesaan. Saat ini kawasan agropolitan yang terbilang sukses pelaksanaannya adalah di segi tiga Agropolitan Kecamatan Pacet - Kecamatan Sukaresmi dan Desa Sindang Jaya dan didukung oleh buffer zone Cugenang dan Sukaresmi. Jaraknya kurang lebih $22 \mathrm{~km}$ dari Kota Cianjur, $108 \mathrm{~km}$ dari Kota Jakarta, dan sekitar $87 \mathrm{~km}$ dari Kota Bandung.Kecamatan Pacet, Kabupaten Cianjur.

Kabupaten Cianjur adalah salah satu kabupaten yang ditunjuk oleh pemerintah pusat dalam pembangunan proyek kawasan terpadu Agropolitan. Kabupaten Cianjur memiliki luas wilayah 350.148 hektar dengan jumlah penduduk berdasarkan hasil sensus penduduk (SP) tahun 2000 berjumlah 1.931 .840 jiwa dengan laju pertumbuhan penduduk 2,11 \%. Lapangan pekerjaan utama penduduk Kabupaten Cianjur di sektor pertanian yaitu sekitar 62,99\%. Sektor lainnya yang cukup banyak menyerap tenaga kerja adalah sektor perdagangan yaitu sekitar $14,60 \%$. Sektor pertanian merupakan penyumbang terbesar terhadap APBD Kabupaten Cianjur yaitu sekitar $42,80 \%$ disusul sektor perdagangan sekitar 24,62\%.

Kawasan Agropolitan di Kabupaten Cianjur terhampar diapit oleh dua desa dari dua kecamatan berbeda, yaitu meliputi dua desa, yaitu Desa Sukatani yang berada di Kecamatan Pacet seluas $376 \mathrm{Ha}$, dan Desa Sindangjaya di Kecamatan Cipanas seluas 512 Ha. Secara keseluruhan luas areal kawasan agropolitan adalah $888 \mathrm{Ha}$ terdapat di wilayah perdesaan yang tidak jauh atau berbatasan dengan wilayah 
perkotaan. Dari luasan itu walaupun sebagian besar berfungsi sebagai areal pertanian, namun didalamnya terdapat pula peternakan, bangunan rumah, bangunan penunjang lain, dan sub terminal.

Sebagian besar penduduk di desa Sindangjaya dan desa Sukatani merupakan petani. Jumlah seluruh penduduk sebanyak 23232 orang, teridir dari Kepala Keluarga (KK) sebanyak 10 985 orang, dimana KK yang mengandalkan hidupnya dari sektor pertanian adalah sebanyak 8982 KK Tani. Dari jumlah rumah tangga pertanian tersebut, proporsi petani dan penggarap adalah 70:30 dengan rata-rata pemilikan tanah seluas 1000-2000 m/petani. Persentase jumlah petani di Desa Sindangjaya sebesar $85 \%$, sedangkan persentase petani di desa Sukatani sebesar 74\%. Rata-rata persentase petani di kedua desa tersebut sebesar $82 \%$.

Hampir 90\% tanah yang berada di kedua desa dimiliki oleh petani setempat dengan sertifikat hak milik, sedangkan sisanya sebesar $10 \%$ tanah dimiliki oleh penduduk / tuan tanah di luar kecamatan dan di luar kota Cianjur. Artinya penduduk setempat memiliki kekuasaan dan keleluasaan untuk memanfaatkan dan mengusahakan tanah pertanian yang dimilikinya.Hanya sayang, luas tanah pertanian setiap tahunnya semakin menyusut seiring dengan bertambahnya jumlah KK karena perkawinan. Setiap KK baru membangun rumah di bidang tanah yang semula merupakan tanah pertanian.

Kawasan Agropolitan dibangun dengan misi meningkatkan kesejahteraan petani. Pembangunan kawasan agropolitan di Cianjur dimulai pada 2003, dan selesai dibangun seluruhnya pada 2006. Pembangunan yang dilakukan berupa penataan wilayah, pembangunan jalan, bangunan tempat packing, bangunan pelatihan, kantor $\mathrm{P} 4 \mathrm{~S}$, dan rumah kompos.

Kawasan agropolitan dikembangkan oleh Pengelola Kawasan Agropolitan yang dibentuk oleh Pemda Kabupaten Cianjur, dan sehariharinya secara operasional lebih banyak ditangani oleh Pengurus P4S. Para pengelola adalah para petani setempat. Ketua P4S ditunjuk oleh P4S binaan dari Lembang BDAH Kayu
Ambon. P4S Cianjur tahun lalu bersama P4S lainnya di Jawa Barat memperoleh penghargaan nasional sebagai petani yang kreatif dan inovatif mengembangkan usaha pertanian. Kegiatan yang dilakukan oleh P4S adalah melakukan pelatihanpelatihan cara bercocok tanam sayur bagi para siswa SLTA dan mahasiswa yang sedang menuntut ilmu tanpa ditarik bayaran. Sementara untuk selain siswa pengurus menarik biaya pelatihan sebesar Rp 200.000/orang.

Pengembangan dan pemeliharaan kawasan agropolitan dilakukan pengurus bersamasama dengan para petani, namun tidak terlembagakan. Secara insidentil mereka melakukan penyuluhan maupun pelatihan, atau penanaman baru jika ada program pemerintah. Selebihnya kegiatan berjalan sendiri-sendiri.

Tiadanya kegiatan atau program yang terstruktur dan alpanya pendanaan yang dianggarkan oleh pemerintah dan pengurus berimplikasi pada absennya evaluasi dan pengawasan. Perkembangan kawasan sangat tergantung pada kemampuan petani secara individual mengembangkan diri dan produktivitasnya. Semakin berkembang dan produktif petani, maka kawasan agropolitan semakin berkembang. Begitu pula sebaliknya, semakin petani menurun kemampuannya, maka semakin reduplah kawasan agroppolitan. Kondisi seperti ini mengakibatkan pamor agropolitan meredup, enggan hidup mati tak mau.

Seharusnya kawasan agropolitan lebih baik dibandingkan keadaan saat ini, karena sudah difasilitasi dengan sarana dan prasarana cukup memadai. Jalan menuju kawasan agropolitan seluruhnya sudah beraspal dengan lebar sekitar 3-4 m, namun sayangnya di beberapa bagian jalan dalam kondisi rusak sehingga menyulitkan pengangkutan. Peningkatan jalan batu menjadi beraspal merupakan dampak positif yang paling nyata dirasakan petani dari adanya kawasan agropolitan.

Di dalam kawasan agropolitan terdapat sub terminal yang menjadi pusat pengangkutan hasil produksi pertanian, namun kondisi sub terminal kurang layak. Jalan yang dilalui terlalu sempit dan kondisi jalan sudah rusak. Sarana yang kondisinya masih baik adalah kantor 
pelatihan, gedung packing dan rumah kompos.

Sarana dan prasarana yang ada jika dikelola dan dimanfaatkan lebih optimal akan mampu meningkatkan pendapatan lebih untuk petani secara langsung maupun untuk para pengelola. Hasil produksi pertanian Kawasan Agropolitan di Cipanas Cianjur disamping memenuhi kebutuhan konsumsi penduduk di wilayahnya juga memasok kebutuhan pangan, khususnya sayur mayur dan daging ayam wilayah perkotaan di sekitarnya (Jabotabek).

Selain hasil produksi pertanian, kawasan agropolitan menjadi penyeimbang dengan wilayah perkotaan di sekitarnya. Pepohonan yang tumbuh menjaga ketersediaan sumber mata air dan memberikan kesegaran udara. Walaupun sebagian besar areal diperuntukkan untuk tanaman hortikultura dengan sedikit tanaman tegakkan untuk menahan longsor dan menyerap air hujan. Penanaman pohon keras atau tegakkan terutama di lereng-lereng bukit sangat penting untuk segera dilakukan.

Setelah selesai dibangun pada 2006, maka praktis tidak ada lagi kucuran dana dari pemerintah pusat untuk mengembangkan dan memelihara kawasan agropolitan. Seharusnya setelah selesai dibangun segera dilakukan serah terima pengelolaan dari pemerintah pusat kepada pemerintah daerah dimana kawasan itu terletak, dalam hal ini Pemda Kabupaten Cianjur. Sehingga kevakuman dan tanggung jawab operasional beralih dan jelas penanganannya.

\section{Sistem Kelembagaan Kawasan Agropolitan di Kabupaten Cianjur}

Sistem kelembagaan terkait dengan proses dimana anggota-anggota masyarakat meningkatkan kapasitas kelembagaannya untuk memobilisasi dan mengelola sumberdaya untuk menghasilkan perbaikan-perbaikan yang berkelanjutan dan merata dalam kualitas hidup sesuai dengan aspirasi mereka. Karenanya diperlukan lacakan aspek historis atau riwayat, baik proses maupun dinamikanya, dan keberlanjutan kelembagaan tersebut (institutional sustainability). Prinsip penting yang harus diidentifikasi dalam kelembagaan lokal :
1. Kelembagaan tersebut merupakan manifestasi dari 'sharing' seluruh stakeholder, dimana pola hubungan dapat ditelaah secara kritis analisis pihak-pihak terkait. Telaah ini penting untuk menetapkan dimana kedudukan organisasi atau badan yang melaksanakan fungsi hubungan kelembagaan tersebut.

2. Fokus " pekerjaan" kelembagaan tersebut adalah aktivitas yang partisipatif dan diperkirakan secara operasional dapat didukung dan difasilitasi oleh beragam kebijakan local government. Matriks antara program-program partisipatif dengan persyaratan kebijakan makro dan regional yang dapat mengidentifikasi beragam kebijakan apa saja yang perlu dirumuskan oleh local government.

3. Kelembagaan tersebut baik secara konseptual maupun operasional mampu mengimplementasikan kaidah-kaidah desentralisasi dan otonomi daerah.

Stakeholder kawasan agropolitan terdiri dari petani, pemasar, pembeli, pemerintah daerah kabupaten Cianjur dalam hal ini Dinas Pertanian, Dinas Perindustrian dan Perdagangan, Dinas Bina Marga, dan kelembagaan lokal yang ada di wilayah setempat.

Pada masa awal pembentukannya di kawasan Agropolitan terdapat Unit Pengelola Kawasan Agropolitan terdiri dari :

1. Departemen Permukiman dan Prasarana Wilayah

2. Departemen Pertanian

3. Pemerintah Kabupaten Cianjur

Setelah pembangunan selesai dibentuklah lembaga pengurus kawasan agropolitan, disebut Pengelola Kawasan Agropolitan (KPA), dengan struktur organisasi : ketua, seorang wakil ketua, seorang bendahara, seorang sekretaris, seksi pemasaran, seksi budidaya ternak, Seksi Pengawasan Lahan, dan Seksi Budidaya. KPA saat ini vakum, tidak lagi menjalankan fungsinya secara berkala. Lembaga lain yang masih menjalankan fungsinya dan secara operasional sehari-hari mengelola kawasan agropolitan adalah P4S. Kegiatan yang dijalankan P4S 
merupakan program partisipatif. Dalam menjalankan kegiatannya, P4S mengandalkan kekuatan sendiri. Belum ada dukungan kebijakan insentif dari Pemerintah Kab. Cianjur).

Pengurus P4S yang aktif hanya 4 orang. Para pengelola tidak memperoleh gaji. Mereka mencari sumber dana untuk pembiayaan overhead dan keperluan lain dari sewa bangunan, shooting, melakukan pelatihan-pelatihan dengan biaya pelatihan $\mathrm{Rp}$ 200.000/peserta termasuk akomodasi dan makan selama mengikuti pelatihan.

Seiring berjalannya waktu, dengan berakhirnya bantuan dana dari Pemerintah Pusat untuk mengembangkan agropolitan, maka menyusut pula kegiatan yang dilakukan Pemda Kabupaten Cianjur.sesekali melakukan pembinaan berupa penyuluhan jika ada dana tersedia dalam anggaran. Dengan kata lain, kelembagaan lokal yang ada di kawasan agropolitan Cianjur baik secara konseptual maupun operasional belum mampu mengimplementasikan kaidahkaidah desentralisasi dan otonomi daerah.

Kawasan agropolitan dibangun dengan tujuan meningkatkan kesejahteraan petani. Untuk mencapai tujuan tersebut, dibangun sistem tata kelola dan kelembagaan agar kemanfaatan kawasan agropolitan dapat terus-menerus dinikmati.

Kawasan Agropolitan Cipanas Cianjur sejak selesai dibangun (tahun 2006) sampai Desember 2012 telah membawa dampak positif terhadap kehidupan para petani di kawasan itu. Dampak positif dirasakan karena pembangunan dan perbaikan prasarana jalan. Jalan beraspal yang sebagian besar masih dalam kondisi baik, memudahkan dan mempercepat para petani mengangkut hasil produksinya. Sebelum dibangun kawasan agropolitan, kondisi jalan masih berupa jalan batu desa sehingga petani sulit mengangkut hasil produksi dan membayar ongkos angkut yang mahal (ojeg motor). Setelah dibangun kawasan, jalan ditingkatkan beraspal selebar $4 \mathrm{~m}$ sehingga hasil produksi tani bisa diangkut dengan roda empat, yang secara langsung mengurangi biaya ongos transportasi.

Areal pertanian di kawasan agropolitan ditanami aneka sayur mayur, seperti wortel, bawang daun, selada, tomat, cabai, kol, dan lainlain jenis hortikultura yang ditanam dengan sistem tumpang sari. Tidak ditemukan sawah di kawasan ini, karena kondisi tanah yang tidak cocok untuk bertanam padi. Seringkali para petani mencoba membuat areal persawahan, namun panen tidak berhasil. Walaupun tidak memiliki sawah, petani di kawasan ini memiliki keahlian menanam tanaman secara tumpang sari dengan teknik bercocok tanam khusus yang berbeda dengan petani di daerah lain. Petani mampu menanam tujuh jenis tanaman pada satu bidang tanah.

Hasil pertanian dijual secara individual. Masing-masing petani telah memiliki pasarnya sendiri-sendiri untuk menjual hasil tani. Sebagian petani menjualnya kepada petani pengumpul atau bandar, sebagian petani lainnya menjual langsung ke pasar Cipanas yang berjarak sekitar $2 \mathrm{KM}$, atau menjual langsung ke pasar-pasar di wilayah Jabotabek. Letak geografis kawasan Agropolitan yang dekat dengan kota-kota besar sangat menguntungkan para petani sehingga mereka tidak kesulitan memasarkan hasil panennya.

Para petani memanen tanaman disesuaikan dengan permintaan dan kebutuhan pasar. Sehingga tidak terjadi panen yang sia-sia karena oversupply yang mengakibatkan harga jual sayur-mayur relatif stabil. Kemampuan menanam secara tumpangsari membuat para petani dapat mengatur waktu panen setiap jenis tanaman sehingga dapat dikatakan mereka dapat menjual tanaman setiap minggunya dan karenanya petani memiliki pendapatan yang cukup dengan perputaran uang relatif cepat dibandingkan petani di daerah lain.

Buruh tani di kawasan agropolitan menerima bayaran sebesar Rp 20.000 netto untuk kerja hingga tengah hari (sampai zhuhur), atau Rp 27.000 jika tanpa makan dan rokok. Sementara khusus buruh panen wortel menerima upah sebesar Rp 200/kg. Pendapatan petani wortel dengan luas tanah $3000 \mathrm{~m}$ sebesar Rp 130 juta, dengan harga jual wortel Rp 7.000/kg.

Beberapa petani yang diwawancarai mengatakan bahwa tidak ada pengelolaan panen di kawasan agropolitan yang dilakukan oleh 
pihak pengelola kawasan. Petani sendiri pun enggan untuk menjual hasil produksinya bersama-sama ke pihak pengelola. Mereka lebih senang menjualnya langsung sendiri-sendiri. Namun sebagian petani memanfaatkan unit packing yang dibangun di tengah kawasan. Penggunaan instansi packing tidak dipungut bayaran, namun petani diharuskan membayar biaya listrik. Jadwal penggunaan instansi packing dilakukan secara bergiliran diantara para petani. hanya 4 saja.

Dampak adanya kawasan agropolitan terhadap peningkatan kesejahteraan petani secara keseluruhan tidak signifikan. Peningkatan pendapatan petani disebabkan bukan karena pengelolaan yang tepat dari pengurus/ manajemen kawasan agropolitan, namun lebih disebabkan oleh kreativitas dan kerja keras petani sendiri.

Tabel 4.3

Kelompok Tani di Desa Pusat Pertumbuhan Agropolitan

\begin{tabular}{|l|l|c|c|l|}
\hline No & $\begin{array}{l}\text { Nama Kelompok } \\
\text { Tani }\end{array}$ & $\begin{array}{c}\text { Jumlah } \\
\text { Anggota } \\
\text { (orang) }\end{array}$ & $\begin{array}{c}\text { Luas } \\
(\mathrm{Ha})\end{array}$ & \multicolumn{1}{|c|}{ Alamat } \\
\hline 1. & Tani Mekar Jaya & 11 & 3,4 & Kp. Gunungbatu, Ds. Sindangjaya \\
\hline 2. & $\begin{array}{l}\text { Tani Surya } \\
\text { Kencana }\end{array}$ & 9 & 3,14 & Kp. Kemang, Ds. Sindangjaya \\
\hline 3. & Tani Padajaya & 10 & 1,9 & Kp. Padajaya, Ds. Sindangjaya \\
\hline 4. & Tani Jolok & 10 & 2,71 & Kp. Jolok, Ds. Sindangjaya \\
\hline 5. & Tani Sukamaju & 10 & 2,68 & Kp. Sindangjaya, Ds. Sindangjaya \\
\hline 6. & Tani Agro Seger & 20 & 10,85 & Kp. Jolok, Ds. Sindangjaya \\
\hline 7. & Kartini & 11 & - & Kp. Kemang, Ds. Sindangjaya \\
\hline
\end{tabular}

Fakta ini menunjukkan bahwa kawasan agropolitan yang awalnya dirancang untuk mengelola hasil produksi pertanian secara bersama-sama dalam satu kesatuan manajemen menjadi tidak terjadi. Kawasan agropolitan yang saat ini terdapat di Cianjur hanyalah merupakan satu hamparan luas areal pertanian yang dimiliki oleh masing-masing petani, dikelola dan dimanfaatkan sendiri-sendiri secara individual. Bukan satu kawasan terpadu yang membentuk kesatuan para petani dan pengelolaannya.

Pada setiap dusun/kampung di desa terdapat 2 kelompok tani. Rata-rata anggota kelompok tani terdiri dari 10 orang. Kelompok tani ini dikukuhkan oleh pemerintah desa dan Dinas Pertanian. Kelompok tani memperoleh penyuluhan dan pembinaan dari Dinas Pertanian. Pada mulanya setiap bulan, namun selanjutnya hanya sesekali saja jika anggaran Pemda tersedia. Hingga sekarang kelompok tani yang masih aktif
Dampak positif lain dari adanya kawasan agropolitan adalah tidak terjadi urbanisasi dan rendahnya pengangguran di kedua desa. Para pemuda usia produktif tidak tergiur untuk bekerja di kota. Mereka tetap tinggal di desa sambil melanjutkan usaha pertanian orang tuanya.. Sangat sulit mencari pengangguran di kedua desa karena hampir semua penduduk desa sibuk bekerja di ladang. Bahkan saat ini desa membutuhkan tenaga tambahan dari desa lain, dengan syarat sebelum diterima bekerja, para pelamar harus mengikuti pelatihan di kantos $\mathrm{P} 4 \mathrm{~S}$ terlebih dahulu.

Kawasan agropolitan dirancang selain sebagai tempat produksi pertanian dan peternakan, juga berfungsi sebagai tempat pengetahuan dan tempat wisata. Namun demikian, fungsi kawasan agropolitan sebagai tempat wisata dan pendidikan belum optimal. 


\section{Kesimpulan}

1. Kebijakan pembangunan kawasan agropolitan di Cianjur mampu menahan laju urbanisasi, menurunkan (menghilangkan) tingkat pengangguran di desa, dan mempertahankan jumlah Rumah Tangga Pertanian, namun gagal mensinergikan para petani agar bekerja sama mengembangkan potensi pertanian wilayah.

2. Kebijakan Agropolitan mampu mengendalikan alih fungsi lahan pertanian ke fungsi lain, dan menekan ketimpangan pemilikan dan penguasaan tanah di Cianjur.

3. Dampak adanya kawasan agropolitan terhadap peningkatan kesejahteraan petani secara keseluruhan tidak signifikan. Adanya peningkatan pendapatan petani disebabkan bukan karena pengelolaan yang tepat dari pengurus/manajemen kawasan agropolitan, namun lebih disebabkan karena kreativitas dan kerja keras petani sendiri secara individual.

4. Pemerintah tidak serius mengimplementasikan kebijakan agropolitan. Rencana kegiatan pembangunan dan pengembangan kawasan agropolitan dalam jangka panjang tidak dijalankan karena terhentinya dukungan (dana, orang, alat) dari Pemerintah Pusat.

5. Pemerintah lemah melakukan monev dan tidak konsisten mengawal kebijakan yang dikeluarkannya.

6. Lemahnya koordinasi dan ketidak adaan integrasi kebijakan/program antar instansi pemerintah untuk mendukung keberhasilan agropolitan dalam jangka panjang. Masingmasing instansi bekerja parsial menurut tupoksinya, sehingga tidak ditemukan akselerasi pengembangan agropolitan.

7. Lambatnya pertumbuhan kawasan Agropolitan dipicu oleh keinginan lemah Petani/sudah puas dan bahagia dengan apa yang mereka peroleh. Tidak ada motivasi kuat untuk meningkatkan produksi. Kesejahteraan petani menurut perspektif petani adalah indeks kebahagiaan, bukan indeks kemakmuran.

8. Budaya waris di masyarakat menjadi faktor pemicu menyusutnya lahan pertanian di kawasan agropolitan menyusut.

\section{Rekomendasi :}

1. Harus dibuat regulasi melalui instrumen insentif dan disinsentif agar tidak terjadi penyusutan lahan pertanian akibat pewarisan dan pernikahan.

2. Peran pemerintah adalah mengawasi distribusi hasil produksi, memastikan tidak terjadi informasi a simetris, mengontrol agar tidak terjadi fluktuasi harga, dan memotivasi petani agar mau meningkatkan produktivitas dan kapasitasnya melalui penyuluhan dan pelatihan-pelatihan, baik pada saat pra, sedang, dan pasca panen.

3. Memfasilitasi agar fungsi kawasan agropolitan sebagai tempat wisata alam dan pendidikan ditingkatkan secara optimal

4. Membangun kolaborasi antar stakeholder, memotivasi petani untuk tidak bekerja secara individual agar produktivitas meningkat namun lingkungan tetap terpelihara.

5. Membuat matriks antara programprogram partisipatif dengan persyaratan kebijakan makro dan regional yang dapat mengidentifikasi beragam kebijakan apa saja yang perlu dirumuskan oleh local government.

6. Meskipun dukungan dana dan fasilitasi dari pemerintah melemah, namun jika ada partisipasi kuat dan entepreuneurship petani, maka kebijakan agropolitan masih bisa berlanjut dan berhasil. Karenanya yang harus dilakukan pemerintah adalah memastikan agar petani mau berpartisipasi dan mengembangkan kapasitasnya termasuk jiwa wirausaha, untuk mengembangkan dan mengolah produk pertanian. 


\section{DAFTAR PUSTAKA}

Bovaird, Tony and Elke Lofler (eds). (2003). Public Management and Governance. London : Routledge.

Bryson, John, M, 1995. Strategic Planning for Public and Non Profit Organizations : A Guide to Strengthening and Sustaining Organizational Achievement. San Fransisco : Jossey-Bass.

Bungin, Burhan. 2007. Penelitian Kualitatif. Jakarta : Kencana Prenada Media Group.

Creswell, W. John. 1994. Research Design : Qualitative and Quantitative Approaches. California : Sage Publications, Inc.

Ernan Rustiadi, Emil Elestianto Dardak. 2008. Agropolitan. Bogor : Crestpent Press.

Friedmann, J., and Weaver, C. 1979. 1980. Territory and Function: The Evolution of Regional Planning. University of California Press, Berkeley.

Mercer. 1991. Strategic Planning for Public Managers. New York : Palgrave Macmillan.

Miller, G., \& Yang, K.2 $2^{\text {nd }}$ edition. 2007. Handbook of research methods in public administration. Boca Raton : Taylor \& Francis Group.

Neuman, W.L. 2007. 2nd edition. Social Research Methods : Qualitative and Quantitative Approaches. Pearson Education, Inc.

Sevilla, Consuello G. 1993. Pengantar Metode Penelitian. Jakarta : Universitas Indonesia. 